\title{
Disruption of Old Structures
}

After a seven-month stay in Copenhagen, on May 22, 1770 Hell and Sajnovics finally left for Vienna, which they reached on August 12. The route they took was different from the outward journey. Instead of a sea voyage to Travemünde, they traveled overland in a southwestern direction, visiting first of all the Academy for Nobles at Sorø, where they met the likes of Gerhard Schøning (172280), a historian specializing in Norway and the ethnographic history of far northern peoples. ${ }^{1}$ Thereafter, they passed through Funen, southern Jutland, Schleswig, and Holstein to Hamburg. From Hamburg, they again chose a more westerly route, this time visiting Göttingen and Kassel before turning straight westward to Düsseldorf and then south through Cologne to Mannheim and Schwetzingen. They then headed east, via Würzburg, Ingolstadt, and Passau to reach Linz, Kremsmünster, Graz, and finally Vienna. The record of encounters with fellow astronomers or other scholars (apart from passing references to whom they met and where) is meager, but a desire to visit as many residences of Jesuit missionaries as possible, as well as observatories and other secular research institutions, appears to have been the reason behind this winding track.

Hell's grandiose dream of a long publicity tour of virtually all Western Europe, as outlined in his letter to the pope before the expedition, thus did not materialize. ${ }^{2}$ Yet, he had no reason for disappointment. He and his companion were elected members of the academies of Trondheim and Copenhagen, and treated in the Danish capital as celebrities. In every respect, the expedition was a success: besides accomplishing the main task, the observation of the transit of Venus, during their nine-month stay in Vardø they carried out systematic work and collected materials in several academic fields whose processing would keep Hell busy for many years. They even managed to analyze some of these materials and publish the results while still in Copenhagen. Although in regard of the transit observation even this was considered late by some fellow astronomers and a bitter controversy ensued, during the two years and three

1 Sajnovics, travel diary, draft version (wUs). On Schøning, see Stian Bones Larsen, "Gerhard Schøning, Gothicism, and the Re-evaluation of the Northern Landscapes," Acta borealia 18, no. 2 (2001): 61-84.

2 As the letter to the pope is the only source where this idea is raised, it is naturally a question how realistic it was to begin with. 
and a half months of Hell's absence from his post, his international reputation became further consolidated and reached a new height. It was from this new height that he may have reasonably expected to resume his activities in Vienna: managing the Imperial and Royal Observatory, editing the Ephemerides, now complemented with working on the Expeditio litteraria as the definitive product of the Arctic journey. However, the climate in Vienna was gradually changing, and around the time of the Vardø expedition the impulse of reform that had begun in the Habsburg monarchy in the late 1740s was turning into its phase known as enlightened absolutism. Roughly simultaneously, and not unrelated to the enlightened turn of reform from above, new platforms and tendencies of intellectual sociability — a critical "public sphere" — began to appear and exert an influence, too. These developments had a significant impact on the Jesuit court astronomer's status and scope of action, and more generally on the conditions of cultivating "Catholic knowledge" in the Habsburg realm.

\section{Habsburg Centralization and the De-centering of Hell}

The status of Hell and his observatory on the domestic and international scheme was an achievement undoubtedly attained thanks to a strategy carefully planned and realized through strenuous work by him and his associates. At the heart of this strategy was the endeavor to answer at all times the contemporary professional and ethical requirements of sound research: commitment, service, and accuracy. However, scientific adeptness and the cultivation of values associated with the dominant scientific ethos, while of paramount importance to the historical agents involved, were by themselves no guarantee of success. That depended on the confluence of several other factors, some of them outside the realm of the pursuit of knowledge. In the given case, these included a (still) powerful and well-networked religious order with a tradition of promoting science (a "science-friendly" Society of Jesus); the patronage of the dynasty and government of a Catholic power; and the choice of a universally accessible language for the dissemination of the information thus obtained in the Ephemerides. Hell's dedication to the Hungarus tradition could also be smoothly reconciled with each of these factors. The harmony among the elements of this combination, however, became subverted shortly after Hell's Arctic expedition; his observation of the transit of Venus and his calculation of the solar parallax had marked the zenith of his career and fame as an astronomer. Many of Hell's subsequent activities and moves-his plan for an Austrian Academy of Sciences in $1774-76$, the uses to which he apparently turned the stock of international recognition embodied in the Ephemerides 
during the later 1770 s and the 1780 s, the increasing number of Germanlanguage publications by him, and so on-may be helpful to interpret as a set of responses to the new circumstances in which a Jesuit scientist in the Habsburg capital found himself after the suppression of his order in 1773. More broadly, they were reactions to the shifting relationship between the Viennese government and the various religious and secular groups and organizations that constituted a challenge to its increasing efforts at consolidating the composite parts of the monarchy as a quasi-imperial Gesamtstaat. ${ }^{3}$

The governmental, administrative, and economic reforms adumbrated in the Habsburg monarchy during the first half of the reign of Maria Theresa were closely tied up with the lessons drawn from the wars it was compelled to fight. International competitiveness depended on a better alignment, mobilization, and utilization of internal resources, which at the same time could also be associated with unfolding ideals of the state's commitment to the public weal. The instruments to attain such ends-administrative streamlining, economic protectionism, customs regulations, the suppression of tax exemptions, and a general endeavor on the part of the state bureaucracy to reach out directly to the subject over the heads of privileged "intermediary powers" - were being tested on Austrian and Bohemian grounds already from the 1740s onwards. This further opened the gap between these areas and Hungary as far as their integration in the structures of the monarchy is concerned. On the one hand, historical experience warned that Hungary would remain "different" (despite the substantial support that the Habsburgs drew from the "insurrection"personal military service: a kind of taxation through shedding one's blood—of the Hungarian nobility throughout the War of Austrian Succession and the

3 The literature on Habsburg enlightened absolutism (or "despotism") is vast. On the concept and its history, see Derek Beales, "Philosophical Kingship and Enlightened Despotism," in Beales, Enlightenment and Reform in Eighteenth-Century Europe (London: Tauris, 2005), 2859, also printed in Mark Goldie and Robert Wokler, eds., The Cambridge History of EighteenthCentury Political Thought (Cambridge: Cambridge University Press, 2006), 497-524. Besides relevant chapters in Evans, Austria, Hungary and the Habsburgs, already mentioned, see H.M. [Hamish Marshall] Scott, "Reform in the Habsburg Monarchy, 1740-1790," in Enlightened Absolutism: Reform and Reformers in Later Eighteenth-Century Europe, ed. H.M. Scott (London: Macmillan, 1990), 145-88; Scott, "The Problem of Government in Habsburg Enlightened Absolutism," in Europa im Zeitalter Mozarts, ed. Moritz Csáky and Walter Pass (Vienna: Böhlau Verlag, 1995), 252-64. The topic has often been discussed comprehensively with the principal actors in the focus. See Franz A.J. Szabo, Kaunitz and Enlightened Absolutism 1753-1780 (Cambridge: Cambridge University Press, 1994); Derek Beales, Joseph II, vol. 1, In the Shadow of Maria Theresa 1741-1780, vol. 2, Against the World 1780-1790 (Cambridge: Cambridge University Press, 1987-2009); Barbara Stollberg-Rilinger, Maria Theresia: Die Kaiserin in ihrer Zeit (Munich: C.H. Beck, 2017). 
Seven Years' War). On the other hand, it was clear that the state could not afford the luxury of dispensing with the resources of its vast and potentially rich eastern half. While keeping up the momentum of reform in the western provinces, it was crucial to generate a similar process in the east as well. By the $1760 s$, a full-fledged know-how of the operation of the reform-minded, bureaucratic, enlightened state was in place at Vienna: Polizeywissenschaft, anchored in the university curriculum and textbooks of Joseph von Sonnenfels, committed to exploring and inculcating the requirements of the safety and convenience (Sicherheit und Bequemlichkeit) of the citizens and thereby achieving the higher ends of the state (Staatszweck). ${ }^{4}$

Central to this administrative (as against rights-and-obligations-based) vision of the state and government was the idea that the existence of all exceptions and exemptions, together with the social groups whose status is defined in terms of such special privileges, is in principle antithetical to the attainment of the above-mentioned goals; that in the eyes of the state all citizens are to be regarded as individuals, bound to the state as individuals, not as members of any legally distinct group or estate. One of the natural targets of policies based on these principles was the Catholic Church. Catholicism as a moral cement and as a force connecting subjects with their ruler in a shared spiritual experience was still regarded as highly important. However, patriotic loyalty elicited by the state's competence in providing, through good laws and their rigorous execution, for the "safety and convenience" of its citizens, began to loom as large on the minds of the architects of the Viennese reforms as the quasireligious devotion to the dynasty. At the same time, Catholicism as an organized hierarchy with a separate structure of allegiances and patronage (which

4 On Polizeywisswenschaft in the larger context of the development of the sciences of the state in the seventeenth and eighteenth centuries in Central Europe, see Keith Tribe, "Cameralism and the Sciences of the State," in Goldie and Wokler, Cambridge History, 525-46; on von Sonnenfels as an emblematic figure in the tradition, see Helmut Reinalter, ed., Joseph von Sonnenfels (Vienna: Verlag der Österreichischen Akademie der Wissenschaften, 1988); Simon Karstens, Lehrer-Schriftsteller-Staatsreformer: Die Karriere des Joseph von Sonnenfels (1733-1817) (Vienna: Böhlau, 2011); on the aspects summarized here, see László Kontler, "Polizey and Patriotism: Joseph von Sonnenfels and the Legitimacy of Enlightened Monarchy in the Gaze of Eighteenth-Century State Sciences," in Monarchism and Absolutism in Early Modern Europe, ed. Cesare Cuttica and Glenn Burgess (London: Pickering \& Chatto, 2012), 75-91, ${ }^{232-36}$ (notes); on the practical impact of von Sonnenfels's courses and textbook, see Olga Khavanova, "Joseph von Sonnenfels's Courses and the Making of the Habsburg Bureaucracy," Austrian History Yearbook 48 (2017): 54-73. On how the consideration of the ordering function of the state was also connected with "statistics" in the sense of the science of the state based on data collection and numbers, see several studies in Gunhild Berg, Marcus Twellmann, and Borbála Zsuzsanna Török, eds., Berechnen/Beschreiben: Praktiken statistischen (Nicht-)Wissens 1750-1850 (Berlin: Duncker \& Humblot, 2015). 
nevertheless deeply infiltrated domains of the secular administration), especially the existence of "idle" enclaves of religious orders, seemed to them a detrimental anomaly. Besides increasing suspicion toward, and ultimately the abolition of these orders, steps toward limited religious tolerance-beginning with minor improvements in the condition of non-Catholics in the later $1770 \mathrm{~s}$ and culminating in the toleration legislation of Joseph II in the 1780 - -also followed from these principles. So did the elimination of church control over education and censorship, and assuming it by the state.

It is important to recognize that while the ensuing reforms did amount to an incremental elimination of the church from an expanding range of spheres of public life, it is more helpful to see them rather as the integration of the church in the management of secular affairs increasingly dominated by the state: as the expansion of the power of the state through its interference in ambiguous areas in the role of the regulator of social tensions. ${ }^{5}$ It was concern about education - famously defined as politicum, a political affair, by Maria Theresa and also central to raising patriotic citizens according to von Sonnenfels's pamphlet Ueber die Liebe des Vaterlandes (On the love of the fatherland [1771]) - that appears to have motivated the empress's first attempts at ecclesiastical reform back in the 1750 s. To be precise, the motivation was exactly pious. In the first, $175^{\circ}$ draft of her "Political Testament," she was critical of the all too generous donations of her predecessors to ecclesiastical orders because "on the one hand they do not need it, and on the other they do not, unfortunately, utilize what they have in the way it should." If we are to judge from the purposes to which the income of ecclesiastical property confiscated later on were turned, "the way it should" meant primarily parish work, in conjunction with popular education, in the expectation that this would improve genuine, personal Catholic devotion. Maria Theresa believed that the condition of her realm in this regard left much to be desired, and required a "great remedy." The first attempt by her and her government to convert these ideas into practice by imposing a ten percent levy on the revenues of monasteries in the mid-1750s was thwarted by the refusal of papal approval. The effort was revived a decade later, at first in Lombardy, where in 1765 the Giunta Economale was created as a bureaucratic unit for exploring the incomes of the church and their uses. In

5 Cf. Michael Mann, "The Autonomous Power of the State: Its Origins, Mechanisms, and Results," in States in History, ed. John A. Hall (Oxford: Blackwell, 1986), 109-36.

6 Josef Kallbrunner and Clemens Biener, eds., Kaiserin Maria Theresias Politisches Testament (Munich: Oldenbourg, 1952), 38, cited in Ernst Wangermann, The Austrian Achievement, 17001800 (London: Thames and Hudson, 1973), 75-76. The whole text is available in Alfred Ritter von Arneth, "Zwei Denkschriften der Kaiserin Maria Theresias," Archiv für österreichische Geschichte 47 (1871): 267-354. 
a memorandum of 1768 to this body (later also redrafted for publication as a pamphlet), Kaunitz-effectively the first minister of the province-formulated a clear-cut position regarding the boundaries between secular and spiritual power. He declared all ecclesiastical matters subject to the jurisdiction of the state, except those assigned by Christ to the Apostles: preaching the Gospels, defining Christian doctrine, performing sacraments and services, and maintaining the inner discipline of the clergy. ${ }^{7}$ From 1769 , the suppression of smaller monasteries (more precisely: their integration in larger ones) in Lombardy began, but the scale remained relatively modest (around one in five), and even more so a few years later on the other experimental ground, newly annexed Galicia. ${ }^{8}$ Further measures taken in 1771 raised the minimum age of taking monastic vows to twenty-four, and limited the "dowry" novices could bring into a monastery to 1,500 florins; in 1772, the number of public holidays was reduced, and pilgrimages were curbed.

While these reforms were still not overwhelming, they indicate a changing climate in Vienna almost exactly during the period of the court astronomer's absence from the Habsburg capital. Besides the initiative taken by Kaunitz, the role of Joseph II, who succeeded his father as emperor and became co-regent with his mother in the Austrian dominions in 1765 , was pre-eminent in the major steps. The most important-indeed, the only really important one during the reign of Maria Theresa-among these was the one that affected Hell most directly: the suppression of the Society of Jesus in 1773. While, as it has been and shall be argued in this book, Jesuit competence was appreciated and resorted to under the reforming regime in Vienna until the last moment and beyond, the order as a corporation had suffered gradual setbacks since the late 175 os. The criticism of Jesuit educational practices (such as the frequent change of teaching personnel, the occasionally all-too-fervent Counter-Reformation programmatics, or the method of university lecturing by sheer dictation from the professor's own manuscripts, resisting the thrust toward the use of standardized textbooks) led to the piecemeal limitation of the role of the Society in Austrian schooling. University chairs in theology and philosophy began to pass from Jesuit hands to members of the secular clergy or representatives of the older religious orders. In Vienna, the Jesuit directors of these faculties were removed by a decree of 1759 and replaced by the Jansenist bishop of Wiener Neustadt, Simon von Stock (1710-72) (followed by Franz Stephan Rautenstrauch

7 Harm Klueting, Der Josephinismus: Ausgewählte Quellen zur Geschichte der TheresianischJosephinischen Reformen (Darmstadt: Wissenschaftliche Buchgesellschaft, 1995), 120.

8 Derek Beales, "Joseph II and the Monasteries of Austria and Hungary," in Beales, Enlightenment and Reform, 227-55, here 233-34; Beales, Joseph II, 1:445-50, and 2:186-92. 
[1734-85], the Benedictine abbot of Braunau) and the reformist canon Johann Peter Simen (1715-75), respectively. The censorship commission, formerly fully controlled by Jesuits, had not a single Jesuit member by the eve of the suppression: what is more, Jesuit works now became indexed because of the condoning of regicide in Jesuit political thought. ${ }^{9}$ From 1760 , Jesuit confessors of members of the dynasty were dismissed one after the other, and in 1767 the empress - whose growing uneasiness with excessive forms of baroque piety and emphasis on private devotion drew her closer to the increasingly influential Jansenists-herself decided to replace in this position the Jesuit Ignaz Kampmiller with the Augustinian and Jansenist (and staunchly anti-Jesuit) Ignaz Müller (1713-82). ${ }^{10}$

At the turn of the 1760 s and 1770 s, the situation was still ambiguous. On the one hand, the Catholic powers of Western Europe that had recently expelled the Jesuits from their lands-including, importantly, the Habsburgs' new ally: France-were pursuing a strong campaign for the wholesale suppression of the Society of Jesus with the newly elected pope, Clement XIV (1705-74, r.1769-74), known to be amenable to listening to them. Influential voices in Vienna, including Van Swieten and von Sonnenfels as well as jurist Karl Anton von Martini (1726-180o), also spoke out in favor of following the example of the Bourbon monarchies. Yet, in 1769-71, when the establishment of a state education system was intensely discussed in the highest government circles, the consensus of the chief decision-makers was that - contrary to a proposal by Count Johann Anton von Pergen $\left(1725^{-1814}\right)$ as minister of state to completely exclude all regular clergy from education-it was impossible to dispense with the contribution of ecclesiastical orders in the field. Given their still central role in education, this was essentially a debate about Jesuits, whom Maria Theresa, Joseph II, and Kaunitz continued to hold in respect, and claimed to be largely innocent of the abuses that led to their expulsion from the other Catholic realms. Even Kaunitz, who by this time seems to have been the most actively hostile of the trio vis-à-vis the monastic orders, thought that Jesuits were not as bad as others, and keenly emphasized that it was the institution that

9 Norbert Bachleitner, Die literarische Zensur in Österreich von 1751 bis 1848 (Vienna: Böhlau, 2017), 50-51. Chapter 2 (41-92) of this book is fully dedicated to censorship "in the service of the Enlightenment."

10 On these developments, particularly in censorship, the most comprehensive, contextualized account is Grete Klingenstein, Staatsverwaltung und kirchliche Autorität im 18. Jahrhundert (Munich: Oldenbourg, 1970). See also Hersche, Spätjansenismus, esp. Chapter 2, 103-62; Winfried Müller, "Der Jesuitenorden und die Aufklärung im süddeutschösterreichischen Raum," in Klueting, with Hinske and Hengst, Katholische Aufklärung, $225-45$. 
ought to be targeted, while the Portuguese, Spanish-Neapolitan, and French practices vis-à-vis individual members, such as incarceration or expulsion, were inhuman and ought to be avoided. ${ }^{11}$ The position of the main decisionmakers on the suppression of the Society of Jesus can be described as one of pragmatic aloofness, aptly summarized in a letter of 1768 by Joseph II to his brother, Grand Duke Leopold of Tuscany (1747-92, r. as grand duke $1765^{-90}$, as emperor 1790-92): "We have not been ready to involve ourselves either for or against, having insufficient reason to desire their destruction, but not regarding their existence as so necessary that we must protect them."12

These were the principles actually followed by the Habsburg government upon the issuance of Clement XIV's breve Dominus ac redemptor noster on July 21,1773 , announcing the suppression of the Society of Jesus on the grounds that it had not only ceased to produce the desired benefits but even gave rise to resentment and strife among the peoples of Christendom, and therefore support must be withdrawn from it. Once the papal decision had been made-and it must be borne in mind that the pope was the sovereign ruler over the Society of Jesus as an international order-the only issue for the Habsburg government was not the dissolution of the 192 houses in Austria and Hungary, but the future of Jesuit property and of individual Jesuits. On both points, the approach of Joseph II, supported by both his mother and Kaunitz, prevailed. The emperor opposed the curia's original plan to transfer the property to the administration of bishops and insisted that it should be taken over by the state, and - again contrary to the wishes of the pope-the Jesuitenfond created out of it was to be turned not only to religious purposes but to re-employing Jesuits as professors, paying pensions to those for whom no suitable job was found, and other educational purposes as well.

A broadly similar pattern of implementation, albeit on a much larger scale, was followed in the more radical steps taken immediately after Joseph had become sole ruler in 1780 . Unlike previously, when the justification for the measures against the religious orders and for ecclesiastical reform altogether was based chiefly on the (real or alleged) abuses found in particular houses, the general principle of "usefulness" now became paramount. The Patent of

\footnotetext{
11 Ferdinand Maas, "Die österreichischen Jesuiten zwischen Josephinismus und Liberalismus," Zeitschrift für katholische Theologie 8o (1958): 66-10o, here 66-67.

12 Cited in Derek Beales, "Maria Theresa, Joseph II, and the Suppression of the Jesuits," in Beales, Enlightenment and Reform, 206-26, here 206. Cf. Beales, Joseph II, 1:460-64. The summary in the whole of this paragraph and the next largely follows Beales's analysis. Cf. also Helmut Kröll, "Die Auswirkungen der Aufhebung des Jesuitenordens in Wien und Niederösterreich: Ein Beitrag zur Geschichte des Josephinismus in Österreich," Zeitschrift für bayerische Landesgeschichte 34 (1971): 547-617.
} 
Toleration, promulgated for the German and Bohemian provinces on October 13, 1781 (and for the rest of the monarchy at different dates over the following months), removed the civil disabilities of Lutherans, Calvinists, and the Orthodox and thus expanded the pool of competent citizens as assets for the state. It was followed on January 2, 1782 by a similar Edict of Tolerance for the Jews. In the same month (in separate decrees for Austria-Bohemia and Hungary) the monasteries of purely contemplative orders were suppressed, and then an inquiry began into those maintained by other orders to ascertain whether they were performing any "useful functions" (including not only education and medical services but also pastoral care). Although about half of them eventually survived this test (with significant regional variation) ${ }_{13}^{13}$ their resources became severely curbed and strictly controlled, their independence and integrity as communities undermined, and their members intimidated.

The noble estates, especially of Hungary, where they stood up in staunch resistance whenever they felt their "ancient liberties and immunities" under threat, were also exposed to the offensive of enlightened government. The latter's attitude to them was ambivalent in ways similar to the case of the Catholic Church and the religious orders. The traditions of social and political leadership accumulated and fostered among the members of the nobility were welcome insofar as they could be harnessed into the service of the newly defined "goals of the state," but to the extent that these traditions were intertwined with a system of constitutional and fiscal-economic privilege, they were seen as an obstacle to good government and undermining the achievement of those goals. Any intention of social leveling was far from the intentions of Viennese policy-makers and the administrative rank-and-file, but the political influence of the nobility was to be counterbalanced and kept in check by the perpetual creation of new offices and reorganizing old ones. Simultaneously, every effort was made to squeeze out of the nobles-by constitutional bullying or blackmail or by other means-some contribution to the financial burden of efficient governance. A conspicuous manifestation of the antagonism that arose was the session of the Hungarian diet in 1764-65. At this assembly, the Hungarian estates, jealous of their privileges, but also infuriated by a series of publications apparently commissioned by the government and directly challenging those privileges, refused the ruler's demand for increased war tax, a general overhaul of the entire system of taxation, and military reform at their own expense. In response, Maria Theresa's government decided to implement its plan by abandoning the dialogue with the estates, and neglecting the diet in its

13 Beales, "Joseph II and the Monasteries," 246-48. 
future pursuit of the much-needed reforms. ${ }^{14}$ This provoked the members of the nobility to a concentrated effort to entrench their ancient privileges, while some of them were to combine this reaction with a vernacular version of enlightened improvement.

A policy line that, however, did smack of an endeavor at homogenization, was the propagation of the use of the German language for an expanding range of public purposes. Decrees issued in 1774, and especially the Ratio educationis of 1777 , contain paragraphs on the desirability of increased teaching of the German language in the schools of Hungary. By 1783 , German became the language of instruction at the University of Vienna. Finally, administration in general all over the monarchy followed. The language decree of April 26, 1784 ordered the replacement of German for Latin as the official language of Hungary (to be effective from November 1, 1784 in central government offices, and in a year's time on the level of municipal administration as well) $).{ }^{15}$ From the point of view of the emperor and his government, there was a perfectly sound rationale for this measure. It was absurd, so the argument went, for a large country to be governed in a dead language that was incomprehensible for most of its inhabitants, while the very fact that this was so proved that the local vernaculars were deficient and thus unsuitable for the purpose. All around Europe, Hungary and Transylvania, along with Poland, were alone in retaining Latin as the language of administration (this was wrong: by the middle of the eighteenth century, the Poles had virtually abandoned the use of Latin in offices), while the example of the French, the British, and the Russians demonstrated the benefits of a uniform administrative tongue. The logical conclusion from these considerations was apparently to promote German to this status in Hungary, many of whose inhabitants already had at least some familiarity with it.

Joseph II's language decree has been described as a turning point in the relationship between Hungary and the ruler: while earlier measures concerned only partial interests or those of the politically sensitive (such as the abolition of religious orders in the one case, and the removal of the Hungarian crown, the symbol of the country's integrity, to Vienna, in the other), this time the very

\footnotetext{
14 The most comprehensive and up-to-date treatment of the Hungarian estates, the diet, and their relationship with the Viennese government is M. István Szijártó, $A$ diéta: $A$ magyar rendek és az országgyúlés 1708-1792 (Budapest: Osiris, 2005). Concisely, see R.J.W. Evans, "Maria Theresa and Hungary," in Scott, Enlightened Absolutism, 189-207.

15 Éva H. Balázs, Hungary and the Habsburgs: An Experiment in Enlightened Absolutism 17651800 (Budapest: Central European University Press, 1997), 205-11; István Soós, "II. József nyelvrendelete és a 'hivatalos Magyarország." in Tanulmányok a magyar nyelv ügyének 18. századi történetéból, ed. Ferenc Bíró (Budapest: Argumentum, 2005), 261-301.
} 
crassness of the initiative triggered a new awareness of the issue of vernacular language in a much wider circle. Though the emperor made it clear that the decree had no intention to force his subjects to abandon their mother tongue, and it only required those who dealt with public affairs to exchange German for Latin, the genie was released from the bottle. A torrent of angry responses from the counties and municipalities of Hungary, formulated by men of superior learning, challenged the decree by pointing to examples of cultural and linguistic tolerance in imperial settings from the ancient Persian king Ahasverus (Xerxes [519-465, r.486-65 BCE]) to the Mongol conqueror Tamerlane $(1336-1405)$. While many of the individual contributions seem to have promoted Magyar, the official position of the counties was in favor of the retention of Latin, partly because of its being the language of science and international communication — as it were, echoing Jean le Rond d'Alembert's (1717-83) observations in the preliminary discourse of the Encyclopédie, where he admitted that the use of Latin was "highly expedient in the works of philosophes; its clarity and precision are of great benefit to those who stand in need of a universal language."16

\section{$2 \quad$ Critical Publics: Vienna, Hungary}

Besides this rudimentary sketch of the aspects of top-down reform that, in one way or another, affected the predicament in which Hell found himself shortly after his return from the north, developments on the broader cultural and intellectual scene with a similar impact need some attention. These amounted to the rise, from the 1760 s and 1770 , of vernacular versions of the Enlightenment in the Habsburg monarchy, thanks to the confluence of local traditions of learning and communication, active engagement with and reception of general European trends, and stimulation by the government's reforming drive. The growing literature on these vernacular Enlightenments - of which, because of the protagonist of this book, this outline shall only tackle briefly the Viennese and the Hungarian - has shown the simplifications of an earlier perspective on the subject, in which they were represented as "unoriginal" and merely derivative, with the "national awakenings" of the educated elites of the peripheral peoples of the monarchy being based on the rejection of the "enlightened absolutist" policies of the imperial center. ${ }^{17}$ With the important

16 Cited in Balázs, Hungary and the Habsburgs, 210.

17 For the common roots of both of these in the "Counter-Counter-Reformation" of the first half of the eighteenth century, see Evans, Austria, Hungary, and the Habsburgs, $36-55$. For 
correctives in mind, it nevertheless remains true that the flowering of Enlightenment both as rational criticism through free and unbiased discussion, and as improvement through the quest, systematization, dissemination, and application of up-to-date knowledge in contexts other than the reform initiatives of the government, owed a great deal to the constant dialogue with it from the outset.

In the case of the rise of an enlightened public in Vienna, ${ }^{18}$ a look at some of the central figures might illustrate this point. Von Sonnenfels - as the son of a recently converted and ennobled teacher of Hebrew, pretty much an outsiderfirst made a mark on the Viennese scene in the Deutsche Gesellschaft (German society) of the early 1760 s, dedicated to promoting the improvement of the German language as propagated by Gottsched, and of vernacular literary culture in general. It was the recognition of his qualities and potential as a local philosophe by the aristocratic reformers around the government, who had personal experience of and were fully conversant with the "world of the Enlightenment" in Paris and elsewhere-besides Kaunitz, members of his Council of State like Egid Valentin Baron von Borié (1719-93), or the Zinzendorf brothers,

correctives to the view of the Enlightenment in the region as "unoriginal" and "derivative," see Teodora Shek Brnardić, "Intellectual Movements and Geo-political Regionalization: The Case of the East European Enlightenment," East-Central Europe/L'Europe du CentreEst 32, nos. 1-2 (2005): 147-77; Brnardić, "The Enlightenment in Eastern Europe: Between Regional Typology and Particular Micro-history," European Review of History: Revue européenne d'histoire 13, no. 3 (2006): 411-35; László Kontler, "Introduction: The Enlightenment in Central Europe?," in Discourses of Collective Identity in Central and Southeast Europe (1770-1945), vol. 1, Late Enlightenment: Emergence of the Modern National Idea, ed. Balázs Trencsényi and Michal Kopeček (Budapest: Central European University Press, 2006), 33-44. For more recent studies of the Enlightenment in the Habsburg realm in nonViennese and non-Hungarian contexts, see Ivo Cerman, Rita Krueger, and Susan Reynolds, eds., The Enlightenment in Bohemia: Religion, Morality, and Multiculturalism (Oxford: Voltaire Foundation, 2011); Marija Petrovič, "Austrian Enlightenment in Cyrillic: Joseph Kurzböck's Cyrillic Printing Shop and the Transmission of the Enlightenment to Austria's Serbs," Austrian History Yearbook 48 (2017): 25-38. On how such studies "redress the habitual imbalance of an Enlightenment historiography [in the Habsburg lands] mainly focused on Vienna," see Franz Leander Fillafer, "Whose Enlightenment?," Austrian History Yearbook 48 (2017): 111-25.

18 For comprehensive treatments, see Oszkár Sashegyi, Zensur und Geistesfreiheit unter Joseph II: Beitrag zur Kulturgeschichte der Habsburgischen Länder (Budapest: Akadémiai Kiadó, 1958); Ernst Wangermann, Die Waffen der Publizität: Zum Funktionswandel der politischen Literatur unter Joseph II (Munich: Oldenbourg, 2004). The topic is explored from the perspective of literary scholarship in Leslie Bodi, Tauwetter in Wien: Zur Prosa der österreichischen Aufklärung 1781-1795 (Frankfurt: Fischer Verlag, 1977). See also Heather Morrison, "Pursuing Enlightenment in Vienna, 1781-179o" (PhD diss., Louisiana State University, 2005). 
Counts Ludwig (1721-80) and Karl (1739-1813) — that led to von Sonnenfels's recruitment to his university chair. ${ }^{19}$ In other words, in the given circumstances these qualities supported his candidacy for a position as a state servant performing strategic tasks in state-building, while at the same time they were deeply rooted in his ability to apply critical common sense to public affairswhich he also did in his simultaneous capacity as a public intellectual. Committed to the ideals of the freedom of expression and the press, and taking advantage of the relaxation of censorship, in 1765 von Sonnenfels launched the first significant Viennese equivalent of European moral weeklies, under a title-Der Mann ohne Vorurtheil (The man without prejudice) - that speaks for itself. This was the first German periodical raising social and political issues directly, ${ }^{20}$ including the improvement of the condition of peasants, the suppression of guilds, restrictions on torture, and the abolition of the death penalty - all based on assumptions about the monarch's legislative obligations deduced from natural law and humanitarian principles. The journal ceased to exist in 1767; in 1769, a new Penal Code—aptly (nick)named Nemesis Theresiana - if anything, only aggravated the regulations on torture and the death penalty; and von Sonnenfels was ordered to stop discussing these issues. In the formal protest he submitted, he stressed his obedience to the existing laws, but also his view that the free criticism of their shortcomings was a key condition to improvement in the administration of the state. That he continued to voice and publish his views on the subject had a part in the abolition of torture in 1776 .

In a like fashion, from the 1760 s on the government demonstrated an increasing awareness of the importance of appealing to and shaping a critical public opinion in canvassing its reform agendas by commissioning or sponsoring publications, whether in opposition to the Hungarian diet or concerning the dissolution of monasteries. In accordance with this recognition, a further relaxation of censorship accompanied the ecclesiastical reforms at the beginning of Joseph II's reign, in order to enable his supporters to counter the clerical protests against these measures. One of the collateral effects was a much greater exposure of the public to the large stock of literature formerly indexed, including most classics and lesser works of the European Enlightenment. In addition, these developments elicited a veritable Broschürenflut, "flood of

19 Grete Klingenstein, "Between Mercantilism and Physiocracy: Stages, Modes, and Functions of Economic Theory in the Habsburg Monarchy, 1748-1763," in State and Society in Early Modern Austria, ed. Charles W. Ingrao (West Lafayette: Purdue University Press, 1994), 181-214.

20 Wolfgang Martens, Die Botschaft der Tugend:Die Aufklärung im Spiegel der deutschen Moralischen Wochenschriften (Stuttgart: Metzler, 1968), 141. 
pamphlets": close to 1,800 opinion pieces and critical essays published within the span of a mere year and a half that, initially as substitutes for a genuine political press, generated eager debate beyond the printed word, in salons, inns, and coffee houses. A prime example of the close intertwining of the political process and the public sphere was the pamphlet Was ist der Pabst? (What is the pope?) by former Jesuit Josef Valentin Eybel (1741-1805). Published on the eve of Pope Pius vi's (1717-99, r.1775-99) 1782 visit in Vienna aimed at persuading Joseph II to revise his ecclesiastical policies, the pamphlet claimed the pope to be merely the first among otherwise equal bishops. Dozens of new journals and newspapers were launched, the volume of the book trade increased significantly, and publishers, booksellers, and lending libraries proliferated. The topics discussed expanded way beyond the one that triggered the process - church reform - and embraced all the typical subjects of enlightened sociability, from virtue and manners, through social orders and emancipation, to new developments in the full array of fields of learning. If not overnight, certainly at a very quick pace, a critical public sphere sprouted in Vienna with "almost as extensive" freedom of debate as in England, according to the British ambassador. ${ }^{21}$

This was as remarkable as it was ephemeral, as the scene began to change in the second half of Joseph II's reign. As the momentum of anti-clerical polemics boosting the government's legislative efforts spent itself, writers increasingly saw themselves not merely as supporters of these efforts, but as "voices of the nation" whose self-appointed task was to critically assess government policies themselves. This attitude was also fostered by their uneasiness with the emperor's headstrong centralism and propensity for authoritarian control, not to speak of his unconcealed, patent contempt for the profession of letters. In the subsequent process of alienation, many of them became disaffected, and during the crisis of the final years of the Josephian regime some of them found themselves in the anti-government camp. This precipitated a new, more restrictive Censorship Patent issued in January 1790, the month before Joseph II's death, in tune with the more general tendencies of the surveillance and control of public opinion by Stimmungsberichte (reports on the people's "mood,"

21 Wangermann, Austrian Achievement, 138. While the commission on censorshiprehashed under the name Studien- und Zensurkommission, initially chaired by von Sonnenfels and then the younger Van Swieten, Gottfried (1733-1803) - certainly kept a close eye on the pamphlets, it is probably an exaggeration that they were effectively commissioned by the government, as suggested by Wangermann, Waffen der Publizität, 11 and passim. For a criticism, and the assertion of a much greater integrity of the contributors, see Morrison, "Pursuing Enlightenment," 44 and passim. 
to be submitted to the emperor weekly by every provincial police chief) and other means. ${ }^{22}$

In many ways, a similar trajectory can be outlined in the case of one of the quintessential venues of enlightened sociability: freemasonry. The first lodge was created in Vienna in 1742, and by the 1780 s there were altogether seventeen of them in the whole of Austria (besides a good number in the other provinces). ${ }^{23}$ Despite the sympathy of Emperor Francis I (who had famously joined a lodge in the Netherlands as early as the 1730s), they faced many difficulties under the devout empress, both on account of their secrecy and obscure ritual, and their real or suspected religious heterodoxy. The accession of Joseph II brought about a change in this regard, although he also warned against the "superstitious" aspects (as he was later to express: the "mumbo-jumbo") of masonic practices, and made it clear that his toleration of them is pragmatic: an acknowledgment of their potential good works, as well as the common sense that prohibition only makes a secret society more attractive. ${ }^{24}$ Nevertheless, also in light of the fact that freemasonry was generally allied with the emperor in his anti-clerical projects, in the early 1780 s there was a wind of opportunity in Vienna for the unrestrained expression and assertion of the masonic commitment to the enlightened values of improvement through the pursuit of virtue, fraternity, and science. ${ }^{25}$

22 Paul B. Bernard, From the Enlightenment to the Police State: The Public Life of Johann Anton Pergen (Urbana: University of Illinois Press, 1991), 115-69.

23 The classic treatment is Ludwig (Lajos) Abafi, Geschichte der Freimaurerei in ÖsterreichUngarn, 5 vols. (Budapest: L. Aigner, 1890-99). In more recent literature, see Helmut Reinalter, ed., Freimaurer und Geheimbünde im 18. Jahrhundert in Mitteleuropa (Frankfurt: Suhrkamp, 1983); Reinalter, Joseph II und die Freimaurer im Lichte zeitgenössischer Broschüren (Vienna: Böhlau, 1987).

24 Karl Gutkas, Kaiser Joseph II: Eine Biographie (Vienna: Paul Zsolnay Verlag, 1989), 326; Beales, Joseph II, 1:486.

25 For a portrayal of European freemasonry in terms of this combination of values, see Margaret C. Jacob, The Radical Enlightenment: Pantheists, Freemasons, and Republicans (Cambridge: Cambridge University Press, 1981); Jacob, Living the Enlightenment: Freemasonry and Politics in Eighteenth-Century Europe (Oxford: Oxford University Press, 1991). It must be added that more recent research has shown this commitment to have been far from universal. Cf., e.g., Nicholas Goodrick-Clarke, The Western Esoteric Traditions: A Historical Introduction (Oxford: Oxford University Press, 2010), 131-53; Cécil Révauger, "English Freemasonry during the Enlightenment: How Radical, How Conservative?, Lumières (Lumières radicales et Franc-maçonnerie) 22, no. 2 (2013): 33-48. For a concise overview of the state of the art in research on freemasonry and its relationship to strands of the Enlightenment, see Róbert Péter, "General Introduction," in British Freemasonry 1717-1783, ed. Róbert Péter, 5 vols. (London: Routledge, 2016), 1. xi-xlvi. 
The vehicle for this was a newly established lodge, Zur wahren Eintracht (For genuine harmony), which first met on March 7, 1781, with von Born as its moving spirit. ${ }^{26}$ Like in the case of von Sonnenfels (also a member of the lodge, and for a while its vice-master), in von Born, too, the character of a public servant and the public intellectual — which otherwise sit awkwardly togetherwere not only reconciled but drew mutual reinforcement. His passion for natural inquiry led him to do cutting-edge research in the earth sciences, and he even defied the laws regulating the publication of information on mines as industrial secrets by publishing, in several languages, an account of his experiences on a journey made in 1770 across the mining regions of Hungary and Transylvania, ${ }^{27}$ earning him membership in several European academies. His organization of several learned associations has already been noted. At the same time, his scientific adeptness combined with his administrative and management skills made this freethinker an ideal candidate for governmental and courtly positions, such as councilor at the chamber of mines and mints, and custodian of the imperial cabinet of natural history. Von Born, who had been a freemason since his Prague years and in the meantime also joined the more radical brotherhood of the illuminati, ${ }^{28}$ was elected master of Zur wahren Eintracht a year after its foundation and a few months after his own entry, in March 1782.

Under von Born's leadership, the constitution of the lodge was democratized, and it quickly began to operate as a substitute academy of sciences, promoting and publishing works in the arts and sciences, and opening a space for lectures and discussions to audiences well beyond the scope of its own membership. The lodge cultivated an ethos not only of virtue achieved through sociability 29 but also of duty, purpose, and strenuous work - persistent intellectual exertion

26 For an analysis of the central role of this lodge in the Viennese Enlightenment, see Morrison, "Pursuing Enlightenment," Chapter 4, 178-242. On von Born, see the literature mentioned above in Chapter 1, $52 \mathrm{n} 45$.

27 Von Born's Briefe über mineralogische Gegenstände auf seiner Reise durch den Temeswarer Banat, Siebenbürgen, Ober- und Nieder-Ungarn was published under the pseudonym of Johann Jakob Ferber in 1774 in Frankfurt and Leipzig, and then in translations in London (1777), Venice (1778), and Paris (1780).

28 On the secret society of the illuminati, founded at the University of Ingolstadt by professor of canon and natural law Adam Weishaupt (1748-1830) in 1776, see Richard van Dülmen: Der Geheimbund der Illuminaten (Stuttgart: Frommann-Holzboog, 1977); Helmut Reinalter, ed., Der Illuminatenorden (1776-1785/87): Ein politischer Geheimbund der Aufklärungszeit (Frankfurt: Peter Lang, 1997).

29 On the overtones of Shaftesburian moral aestheticism in the Viennese Enlightenment, see Ernst Wangermann, “'By and by we shall have an enlightened populace': Moral Optimism 
and the regular discussion of its outcomes with fellow masons at reading sessions specifically designed for this purpose (Übungslogen) — and the social responsibility of men of learning to effect positive change. ${ }^{30}$ Besides the more arcane Journal für Freymaurer (Journal for freemasons) intended for masonic audiences, from 1783 Zur wahren Eintracht also published as its own learned journal the Physikalische Arbeiten der einträchtigen Freunde in Wien (Works in physics of the harmonious friends in Vienna), dedicated to the dissemination of specialized but synthetic knowledge, aimed at the general public and presented as conducive to progress, about the "physics" of the lands of the Habsburg monarchy. ${ }^{31}$ This was a broadly understood concept, derived, as in physiocracy, from physis: besides natural history in the strict sense, the purview of the journal included topics like agriculture and mining and so forth, in a cameralist perspective. On top of the patriotic endeavor, placing domestic developments in the context of recent advances in these fields in the international Republic of Letters, and the ambition to integrate Austrian scientific discourse in it, added a distinctly cosmopolitan flavor. Zur wahren Eintracht became a coveted target for foreign visitors in the Austrian capital—several of them also inducted as members - while letters of introduction from the lodge carried by members during their own travels identified them as its representatives and gave them access to similar exclusive venues of sociability all over Europe.

The reasons for the brevity of the flourishing and the quick demise of Zur wahren Eintracht and, more generally, freemasonry in the Habsburg realm in the later 1780 s, are too complex and controversial to discuss here in any detail. The insufficient "density" of true "republicans of letters" who could be mobilized for the scientific-philanthropic-universalist-patriotic utopia of the lodge and the Physikalische Arbeiten; the loss of leverage from the illuminati after the banning of the order in Bavaria (where it had originated) in 1784; tensions among the lodges in regard of the overall direction and institutional strategy of freemasonry; tensions between von Born and von Sonnenfels; and

and the Fine Arts in Late-Eighteenth-Century Austria," Austrian History Yearbook $3^{1}$ (1999): 1-15.

$30 \quad$ Morrison, "Pursuing Enlightenment," 201, 210-12.

31 On the journal, its relation to the lodge, and their integration in the scene of Viennese intellectual and scientific sociability, see Heather Morrison, "Harmony and Discord in the Sciences: Vienna's Scientific Enlightenment and Its Engagement with the Republic of Letters," in Multiple kulturelle Referenzen in der Habsburgermonarchie des 18. Jahrhunderts, ed. Wolfgang Schmale, Das achtzehnte Jahrhundert und Österreich 24 (Bochum: Dieter Winkler, 2010), 103-22. 
other internal factors played a part. ${ }^{32}$ The decisive blow, however, was dealt by the Patent on Freemasonry, issued on December 11, 1785 by Joseph II, who was always ambivalent about the movement, and decided to bring it under stricter control in line with the general thrust toward greater surveillance over the public sphere. There was to be only one lodge per provincial capital, obliged to regularly report to the police about meetings, membership, and so forth.

According to the German naturalist, philosopher, traveler, and later "Jacobin" Georg Forster (1754-94), who joined Zur wahren Eintracht during a visit to Vienna, "the first occasion for the reform of freemasonry in Austria arose from the secret gatherings of the Hungarians, who wanted to work against the system of the emperor. Namely, these gentlemen used masonic meetings as the pretext to discuss the principles of their opposition."33 This observation leads us to the last contextual aspect we briefly need to consider before resuming the narrative of Hell's trajectory in the 1770 s and 1780s: the Hungarian Enlightenment, ${ }^{34}$ whose relevance to this section arises from Hell's newly conceived interest in the Hungarian language and history, and more generally in his country of origin.

As regards freemasonry in Hungary, by 1775 it had developed its own, fullfledged "Constitutional System" - the Draskovich Observance, so named after one of the founders ${ }^{35}$ - and soon enough it united "the best brains of all the counties," as eminent writer Ferenc Kazinczy (1759-1831) wrote of the Pest lodge Magnanimity in his recollections. ${ }^{36}$ Besides organizational issues, one noteworthy feature of the constitutions is the assignment of various tasks to different classes of the brethren, while all of them were required to seek the

32 Morrison, "Harmony and Discord in the Sciences," 120-21; Karstens, Lehrer-SchriftstellerStaatsreformer, 269-75.

33 Forster (conveying the account of a Galician official) to Christian Georg Heyne, October 12, 1786, cited in Reinalter, "Ignaz von Born und die Illuminaten," 364. Cf. Wangermann, Waffen der Publizität, 126.

34 For overviews in Western languages, see Moritz Csáky, Von der Aufklärung zum Liberalismus: Studien zum Frühliberalismus in Ungarn (Vienna: Verlag der Österreichischen Akademie der Wissenschaften, 1981); Domokos Kosáry, Culture and Society in Eighteenth-Century Hungary (Budapest: Corvina, 1987); Gábor Vermes, From Feudalism to Revolution: Hungarian Culture and Politics in the Habsburg Monarchy, 1711-1848 (Budapest: Central European Press, 2014).

35 János Draskovich (1740-81). Previously, the Hungarian lodges had been under the direction of the Grand Landlodge of the Freemasons of Germany. An excerpt from the new "system" has been published in the valuable source collection Réka Lengyel and Gábor Tüskés, eds., Learned Societies, Freemasonry, Sciences, and Literature in 18th-Century Hungary (Budapest: MTA Bölcsészettudományi Kutatóközpont, 2017), 157-61. See also Balázs, Hungary and the Habsburgs, 137-42.

36 Cited in Balázs, Hungary and the Habsburgs, 270. 
best ways of reconciling love for the fatherland with the love of mankind, serving the public good, and discovering the morality conducive to the attainment of these ends. These endeavors were in harmony with individual initiatives aimed at improvement and taking momentum during the same period-in a predominantly agrarian country, almost necessarily in forms such as establishing model farms, or launching philanthropic and educational projects to better the lot of the peasantry. Many of these evolved from local antecedents, including the increasing emphasis on the values of social welfare and harmony in the reception of German Pietism early in the eighteenth century, which also inspired an early beginning of Staatistik, "the science of the state": the collection and systematization of data on geography, natural resources, history, and legal and political institutions as exemplified by the Notitia Hungariae (Description of Hungary [1735-42]) by Bél. The same development can also be traced back to the thrust of the early Enlightenment that would be the most influential in Hungary, along with the rest of Central Europe: the one hallmarked by the name of Christian Wolff, in which the emancipation of the individual was seen as part of a process whereby it was mainly order and efficiency that were to be increased in society, with a very serious role assigned to established authorities. All of these trends received a further strong impetus from Josephism, so it is small wonder that, by the early 1780 s, Hungarian freemasons, Hungarian adherents of the Enlightenment, and Hungarian Josephists were broadly overlapping constituencies. They included noblemen and aristocrats trained at the Theresianum as well as bureaucrats and lawyers, clergymen, and members of an arising secular intelligentsia, many of whom had their education at leading German, Dutch, or Swiss Protestant universities. Men among them like Count Ferenc Széchényi (1754-1820), founder of the collection that became the Hungarian National Museum and Library; his secretary, the splendid lawyer József Hajnóczy (1750-95), regarded as the first Hungarian liberal; the petty nobleman and outstanding economic writer Gergely Berzeviczy (1763-1822), and many others were prepared to go a long way in assisting the headstrong emperor in the implementation of his ever more autocratic reform measures.

The limits of such willingness can be deduced from another feature of the "Constitutional System" of Hungarian freemasonry: its strong indebtedness to Montesquieu (1689-1755). While Voltaire and Rousseau, as well as other major and minor figures of the French Enlightenment were widely read and appreciated in Hungary, despite censorship, none of the philosophes had an intellectual impact on the scale of Montesquieu. ${ }^{37}$ Besides many other aspects of műveinek és gondolatainak fogadtatása a 18. század végétől napjainkig Magyarországon,” Irodalomtudományi Közlemények 116, no. 1 (2012): 3-21. 
Montesquieu's oeuvre, this was substantially owing in general to his analysis of monarchy in the Spirit of the Laws (1748) as a system dependent on the vitality of "subordinate or intermediary powers," and in particular to his illustration of this point in a remarkable passage of book 8 , Chapter 9 by a tribute to the Hungarian nobility, which-despite the endeavor of the house of Austria to "oppress" it- "forgetting the injuries done to themselves, took up arms to avenge her cause." ${ }^{38}$ This was understood by enlightened Hungarians as a gesture both to the virtue and honor of their political elite and to the liberties enshrined in the assemblage of their ancient customs and statutes, soon to be reinterpreted as a constitution established on the principle of the separation of powers. ${ }^{39}$ The injunction of the Hungarian masonic constitutions to brethren-especially those in the legal profession-to inquire into the best form of government and into the nature of their country's constitution was an acknowledgment of the quasi-biblical status of Montesquieu's text among them, with the implication that the pursuit of the enlightened goals of freemasonry was compatible with the preservation of Hungary's political system and autonomy. From this vantage point, the administrative reforms of Joseph II in the mid-1780s - the German-language decree, already mentioned; the imposition of a second tier of administration by "districts," packed by reliable bureaucrats, over the traditional institutions of self-government by counties; the commissioning of a country-wide census, suspected of anticipating a circumscribing of the nobility's tax privileges - were viewed with anxiety, and caused the kinds of stirrings described by Forster.

The completion of the census was an apparent success for Joseph II, but together with the creation of the district system it created an irreparable breach between him and the counties, whereas the language decree was not only impossible to put into practice but also gave impetus to the unfolding movement for the modernization and the embellishment of the Hungarian language. This endeavor was not entirely new in the mid-178os. Its hotbed was Habsburg enlightened absolutism itself, providing training for many young Hungarian nobles in the Theresianum or the Royal Hungarian Bodyguard in Vienna, and employing them on missions into the western centers of social

38 Montesquieu, The Spirit of the Laws (Cambridge: Cambridge University Press, 1989), 119. The passage commemorates the Hungarian nobility's spectacular show of support for Maria Theresa at the outset of the War of Austrian Succession.

39 László Péter, "Montesquieu's Paradox of Freedom and Hungary's Constitutions 17901990," History of Political Thought 16, no. 1 (1995): 77-104, republished in Péter, Hungary's Long Nineteenth Century: Constitutional and Democratic Traditions in a European Perspective, ed. Miklós Lojkó (Leiden: Brill, 2012), 153-82. 
and intellectual ferment. The "bodyguard-writers" 40 became familiar, among other things, with the movement for the improvement of German, which developed into the language of Goethe (1749-1832) by the 1770s. The publication of The Tragedy of Agis in 1772 by the most outstanding among them, György Bessenyei (1746-1811) is usually considered to mark the starting point of a similar process in the case of Hungarian. Bessenyei went on to publish pamphlets on educational policy, endorsing Maria Theresa's comprehensive educational reform, the Ratio educationis of 1777 , but emphasizing the need for the extensive use of Hungarian. In order to make the language worthy of that task, in 1781 he also proposed the establishment of a "patriotic" learned society dedicated to the cultivation of letters in the vernacular. ${ }^{41}$

The linguistic and literary revival thus began to overflow into a general cultivation of native traditions: a sizeable elite group was emerging whose members' cultural and intellectual sensibilities were broadly European, but whose identity was shifting from Hungarus to Magyar. It is also worth emphasizing that their vision of the future restoration of the erstwhile greatness of the Hungarian nation was predicated on galvanizing their own class to a new dynamism through modern letters and knowledge practices. This was a vision of improvement that, in their own view, depended on maintaining a discourse of identity built on a prestigious pedigree and social exclusiveness, both under serious attack from the mid-176os by the Viennese court and government, toward which their attitudes were therefore highly ambivalent. The oeuvre of Bessenyei, who was not only a writer but also an accomplished moral and social philosopher, testifies to such ambivalences in a way that, as we shall see, is highly relevant to Hell's recently conceived interests in the Hungarian language and history.

40 On the Hungarian Guards, with references to the figures mentioned, see László Deme, "Maria Theresa's Noble Lifeguards and the Rise of the Hungarian Enlightenment and Nationalism," in The East Central European Officer Corps, 1740-1920s: Social Origins, Selection, Education, and Training, ed. Béla Király and Walter Scott Dillard (Boulder, CO: Columbia University Press, 1988), 197-212. The Hungarian-language literature is respectable. However, historians have hitherto largely yielded the field to literary scholars, whose main preoccupation has been the rise of vernacular literature and are yet fully to discover the subject and approach it with their own questions. The standard monograph is Ferenc Bíró, A felvilágosodás korának magyar irodalma (Budapest: Balassi Kiadó, 1994), esp. 6992, 161-85;

41 [György Bessenyei], Egy magyar társaság iránt valójámbor szándék, excerpts in English as A Benevolent Plan for a Hungarian Society, published in Lengyel and Tüskés, Learned Societies, 80-89. 
Among many other literary pursuits and genres, Bessenyei was active in the field of philosophical history, ${ }^{42}$ translating and adapting texts by Voltaire, Claude-François-Xavier Millot (1726-85), Louis-Sébastien Jacquet de Malzet $\left(1715^{-1800}\right)$, and Vaissète, and writing original works devoted to the history of Hungarians in the period of settlement and state foundation in a European context, through a comparative analysis of manners, laws, and institutions. In his A magyar nézó" (Hungarian spectator [1779]), Bessenyei surveyed the history of the world, from a Hungarian perspective, in a thoroughly Voltairian framework. He proposed to give an account of the successive stages of the "mitigation" of rude manners, resulting from religion and learning, but also claimed that military glory and polite letters, rather than being antagonistic, could mutually supplement one another. ${ }^{43}$ This, of course, dovetailed with his overall conviction that vera nobilitas, "true nobility" could derive from proficiency in letters as well as arms-bearing, a claim he made to urge a re-evaluation of the social roles of the nobility, which he still regarded as the chief repository of improvement - although it also depended on "emulation between the great and the little." ${ }^{44}$ Then, in A magyar nemzetnek szokásairul, erköltseirül, uralkodásának modjairul, törvényeirül, és nevezetesb viselt dolgairul (The customs, manners, modes of government, laws, and important deeds of the Hungarian nation [1778]), he again provided a set of present-oriented historical reflections, intended as a historical underpinning of his program. Achievements by the sword and by the pen are represented, in a somewhat labored fashion, as two equally feasible paths to ennoblement-although Bessenyei held that among certain circumstances, such as in eleventh-century Hungary and Europe as a whole, the one took precedence over the other. His point in this work is, ultimately, the parallel development of society in Hungary and Europe in the past, and the consequent chance to re-establish synchronicity for Hungary with European progress in the present. (It is tempting to recognize here an association with the notion advanced by Montesquieu, that the shared "deep structures" of European societies predestine them to progress toward a similar present and future, despite the empirical variations within the overall system of monarchy based on intermediary powers.) "It seems as if the Hungarian nobility originated fully from warfare. It could not have been otherwise, for in old

42 On the views of Bessenyei and his fellow "bodyguard writers" on history, see Bíró, A felvilágosodás, 161-86; and Penke, Filozofikus világtörténetek és történetfilozófiák, 161-82.

43 György Bessenyei, Magyarság; A Magyar Néző, Magyar irodalmi ritkaságok 16 (Budapest: Királyi Magyar Egyetemi Nyomda, 1932), 17.

44 György Bessenyei, A Holmi, ed. Ferenc Bíró, György Kókay, and Andor Tarnai (Budapest: Akadémiai Kiadó, 1983), 16. 
times it was impossible to rise to nobility by writing and the pen in a nation, which could neither write nor read, but only fought, triumphed, plundered, and ruled." But Bessenyei adds immediately that "all nations in the world, which have since developed arts and sciences, began their nobilities in this way [...]."45 An appendix entitled "Egész Európa' formája a XI ${ }^{\text {dik }}$ Százban" (The form of the whole of Europe in the eleventh century-excerpted from Voltaire's Essai sur les moeurs, chapters 39-46) is intended to demonstrate that in those times Hungarians were no more barbarous than other European nations. "If you observe only Hungary in the eleventh century, you will find that it dealt improperly with its kings; but was there anything other nations did not commit, although they had been Christians for a long time?"46 Religious war and forced conversion is also described as the order of the day. The ubiquity of violent passions and ignorance was directly related to the overall rusticity of manners: "The sum of customs and manners was excessive eating and drinking, pillage, recklessness in combat, and cruelty." 47

Thus far, this is more or less the standard Enlightenment narrative $e^{48}$ of the feudal past, with the potential of the assessment of the present in equally standard terms of enlightened patriotism. Bessenyei indeed hinted at the anachronistic distribution of social power and privilege in eighteenth-century Hungary: in the beginning,

the plowman paid taxes to the bearer of arms in return for his own protection. So, in old times everything was based on services; but since servants became masters without bearing arms, the one part always obeys, and the other always commands. [...] This great nobility was once a standing army; now they lay idle in their homes [... ${ }^{49}$

Bessenyei, however, nowhere arrived at the explicit conclusion that noble privileges, being no longer justified, ought to be eliminated, although — as the

45 György Bessenyei, A magyar nemzetnek szokásairul [...], in Bessenyei, Összes müvei: Társadalombölcseleti írások 1771-1778, ed. Péter Kulcsár (Budapest: Argumentum-Akadémiai Kiadó, 1992), 89-154, here 96.

46 György Bessenyei, “Egész Európa’ formája a XI ${ }^{\mathrm{dik}}$ Százban," in Bessenyei, Társadalombölcseleti írások, 155-66, here 164.

47 Bessenyei, "Egész Európa' formája," 163.

48 For this concept and its application to mainstream Western European material, see Karen O'Brien, Narratives of Enlightenment: Cosmopolitan History from Voltaire to Gibbon (Cambridge: Cambridge University Press, 1997); Pocock, Barbarism and Religion, esp. vol. 2, Narratives of Civil Government (Cambridge: Cambridge University Press, 1999).

Bessenyei, A magyar nemzetnek szokásairul, 153. 
commissioner of Hungarian Protestants in Vienna-he was more inclined to compromise with the policies urged at court in social and national as well as confessional issues than most others. On the contrary: assigning an unassailable social preeminence to the nobility on account of its historical roles, what he sought was a new justification for these roles, to be found in superior learning, while he still regarded the gulf that separated the nobility from the peasantry as unbridgeable.

Bessenyei supported this by referring to Werbőczy and his own A'törvénynek útja (Of the course of the law [1777]). As a matter of fact, as the whole of this treatise addressed the relationship of the nation and the ruler in law-making, its topic and argument closely followed Werbőczy, whose work Bessenyei was obviously thoroughly familiar with. His claim that the people raised "captains" and masters above themselves through the voluntary consent of all echoes the relevant passages of the Tripartitum as well as Kézai's Gesta-although without explicit reference to the Huns and the presumed continuity with the Hungarians, in its political terminology recalling the staples of Scythianism. ${ }^{50}$ The same applies to the justification of differences between the "people" and the "common folk": more generally, in terms of voluntary subordination of the cowardly to the brave warriors, and specifically by reference to forfeiture of right as a result of rebellion (almost a word-by-word quotation of Werbőczy's argument from the consequences of the 1514 peasant war). ${ }^{51}$

In a later work, Magyarországnak törvényes állása (On the legal status of Hungary [1802]), Bessenyei leaves no doubt that his strong commitment to important Enlightenment values and goals was fully compatible not only with this kind of social conservatism but also with cherishing the medieval legacy of the Hun-Hungarian discourse of origin:

The people of Áttila is marked by triumph, valor, thirst for glory, and prudence required for domination, despite its paganness, ignorance, and ferocious nature. The only thing Attila wanted was conversion to Christianity, together with his foremost men, like Saint Stephen. Had he formed a kingdom and settled in his country in a Christian manner, no court would have been superior to his in the prudent wisdom of government, in splendor, wealth, triumph, and glory. ${ }^{2}$

50 György Bessenyei, A' törvénynek útja, in Bessenyei, Társadalombölcseleti írások, 167-90, here 175 .

$5^{1} \quad$ Bessenyei, A' törvénynek útja, 177.

52 György Bessenyei, Magyarországnak törvényes állása, in Bessenyei, Összes müvei: Prózai munkák, 1802-1804, ed. György Kókay (Budapest: Akadémiai Kiadó, 1986), 209-54, here 233 . 
Soon enough, the "moral strength and dignity" identified in the Huns by Bessenyei is associated with the fundamental character of the Hungarians:

The Hungarian nation has always lived by prudence; it has always been governed under freedom, and was full of princely men. For such were the captains. The fight, war, triumph, has been its nourishment and domestic art since time immemorial. Its moral talent is not surpassed by any nation in the world. If it applies itself to science, art, or gallantry, it excels. And if it lags behind the English, the German, and the French to a certain extent, this is not because of its feebleness, but because it does not possess the proper ways and means. It has already been established, that until elevating its own language, no nation in the world will be learned, nor any has ever been. ${ }^{53}$

In what appears an amazing flight of fancy, Bessenyei proceeds from a eulogy of Scythian-Hun-Hungarian military prowess through the supposedly concomitant adherence to the values of liberty and the resulting proneness to excel in learning as well, to the urging of the establishment of a Hungarian academy of sciences, dedicated to the cultivation of the mother tongue as a tool of raising the nation to the status it deserves among modern European nations. However, in view of Bessenyei's overall intellectual project, and his program for social and cultural reform in Hungary, this is not at all surprising. Hailing the Hun-Scythian ancestry of Hungarians was intimately connected with standing up for a notion of national dignity understood in terms of ancient constitutional liberties that were being undermined by a purportedly enlightened but increasingly autocratic regime.

Where does this inevitably selective sketch of strands of the Enlightenment in the Habsburg monarchy leave us with regard to the purpose it serves, an assessment of the prospects Maximilian Hell had shortly after his return from the northern expedition to Vienna? The changes brought about in his personal circumstances amid these broader processes of transformation compelled him to re-situate himself on the Central European map of learning. Previously, it was relatively easy for Hell to reconcile his loyalties to the Habsburg dynasty and the ruler, to the Catholic Church and the Jesuit order, to the multi-ethnic and multi-confessional Kingdom of Hungary, and to the international Republic of Letters (together with the Latinate culture that marked each of the latter three). His position as imperial and royal astronomer (thus, a state servant) proved to be unassailable, nor did he ever cease to issue his Ephemerides. However, 
the suppression of the Society of Jesus and the overall context of reform and Enlightenment in the Habsburg monarchy meant the breakdown of the harmony that had existed among these various loyalties, and the air around him became thinner. Hell could either choose to accommodate to the new culturalpolitical climate and make the most out of it, or try to remain in contact with a network of loyal ex-Jesuits and other conservative forces. In a way, he did both. Above all, he reacted actively, feeling a need to create new institutional leverages, to forge new social alliances, and to develop new intellectual allegiances in order to maintain the status of authority he had attained during his career up to that time. Before following him on this path, let us briefly consider generally the impact of the suppression of the Society of Jesus on the personnel and infrastructure of Jesuit learning, particularly in Hell's field, in the Habsburg lands.

Between the suppression of the Society of Jesus and the death of Hell in 1792, new conditions for astronomical activity arose in the former Austrian province of the order. As mentioned above, Hell remained at his workplace after the suppression, but his case was special since his institution had been founded and was funded by the state. Other observatories and observers experienced a different plight. These include the Jesuit observatories of Vienna, Cluj, Buda, Graz, and Trnava; and other locations of institutionalized astronomy, such as Lviv, Melk, and Lambach, where ex-Jesuits ${ }^{54}$ had a role to play.

While authors with pro-Jesuit leanings have usually emphasized the detrimental effect of the suppression on the cause of science, ${ }^{55}$ others have argued that at least as far as the "favorite pet" of Jesuit scientific activity — astronomy is concerned, "the status of ex-Jesuits [in it] remained unchallenged,"

54 "Ex-Jesuit" has been used in at least two different meanings: those who, through voluntary exit or as the result of expulsion, left the Society after having delivered their vows, usually after spending a relatively long part of their life as a member; and those who, through the suppression of the order sanctioned by the church in 1773, were freed from their vows and forced to take another direction in their life. Cf. Hermann Haberzettl, Die Stellung der Exjesuiten in Politik und Kulturleben Österreichs zu Ende des 18. Jahrhunderts, Dissertationen der Universität Wien 94 (Vienna: Verband der wissenschaftlichen Gesellschaften Österreichs, 1973), 9. Here, it is used only in the second sense.

55 See, e.g., John (Johann) Schreiber, "Jesuit Astronomy," parts 1-2, Popular Astronomy 12 (1904): 9-19, 94-112; Steinmayr, "Geschichte der Universitätssternwarte."

56 Haberzettl, Stellung der Exjesuiten, 196. 
more specifically that "the dissolution of the Jesuit order had almost no impact on the work at the Vienna Observatory." ${ }^{57}$ This would have been in conformity with the overall situation of Jesuits in the Habsburg lands after the suppression. Whereas in Western Europe large numbers of Jesuits had been either imprisoned or expatriated and deported to the Papal States, in Austria and its hereditary lands the former Jesuits were allowed to stay. As Weltpriester (presbyteri saeculares, "secular priests"), they were given state pensions. In the field of learning, although former Jesuit professors of theology and philosophy proper were in most cases replaced, quite a few professors in other branches of science found themselves in a position where they could continue their careers. The personal trajectories of some of Hell's interlocutors mentioned earlier in this book may illustrate the complexity of the picture. György Pray at first languished in a rather meager priestly position in the diocese of Esztergom, but then he was accorded by Maria Theresa the title historiographer royal for Hungary, and in 1777 he was appointed first custodian of the University Library in Buda. Both of the two Trnava history professors, Katona and Kaprinai, were initially lodged to parishes in the same diocese, but the former was then able to reclaim his chair at the university relocated to Buda. On a larger plane again, while some former Jesuits of the Austrian provincechoseemigration, mainly to Prussia and Russia, ${ }^{58}$

57 Kastner-Masilko, Triesnecker, 47.

58 In the Prussia of Frederick the Great, all former Jesuit gymnasia as well as the Jesuit university in Wrocław (Breslau) were taken over by the state, but the former Jesuit staff was allowed to continue, meaning that the education system remained effectively unchanged, to the dismay of Voltaire among others. See Hermann Hoffmann, Friedrich II von Preussen und die Aufhebung der Gesellschaft Jesu, Bibliotheca Instituti Historici S.I. (Rome: Institutum Historicum Societatis Iesu, 1969); cf., e.g., James van Horn Melton, Absolutism and the Eighteenth-Century Origins of Compulsory Schooling in Prussia and Austria (Cambridge: Cambridge University Press, 1988), 171-99. In the parts of the old Polish assistancy of the Society of Jesus, annexed to Russia as a result of the partition of Poland in 1772, the few hundred Jesuits who were around were never secularized, but reorganized themselves around a new general "in diaspora." Catherine II protected them for the same reason as her Prussian counterpart, seeing that they were essential to the school system. Jesuit centers existed in the form of four collegia, in Polack (Polock, Polotsk), Viciebsk (Vitebsk), Orsha and Daugavpils (Dźvinsk, Dvinsk, Daugpilis), and two principal residences, in Mstislav (Mścisław) and Mogilev (Mohylów). In the first half of the 1780 s, a novitiate as well as a tertianship (house for the third year of probation) was set up in Polack, thus a complete program of Jesuit formation was in place. This elicited a certain degree of immigration of former Jesuits from European states where the Society was still suppressed. See Daniel Beauvois, "Les jésuites dans l'Empire Russe 1772-1820," Dix-huitième siècle 8 (1976): 257-72; Marek Inglot, La Compagnia di Gesù nell'Imperio Russo (1772-1820) e la sua parte nella restaurazione generale della compagnia (Rome: Editrice Pontificia Gregoriana, 1997); Ludwik Grzebień, "II. Provincia de la Rusia Blanca (1773-1820)," in the entry on "Rusia" in O’Neill and Domínguez, Diccionario histórico de la Compañía de Jesús, 4:3441-49; Daniel R. Schlafly, "The Post-suppression Society of Jesus in the United States and Russia: Two 
some others even ended up as bishops or senior officials in the state bureaucracy. 59

In the strictest sense, the positive assessment of the prospects of "ex-Jesuit astronomy" is not far from the truth. Despite radical changes in the institutional organization of science in the Habsburg lands in the wake of the year 1773, the Imperial and Royal Observatory of Vienna remained intact. The number of assistants may have been reduced, but the court astronomer himself sat safe in his chair. While his colleagues abroad feared that the Ephemerides might be discontinued or the Imperial Observatory shut down, ${ }^{60}$ nothing of the sort happened. Instead, the annual volumes of the Viennese almanac were churned out of the press as before (albeit, as we shall see, with some significant changes of emphasis in content), with supplements presenting long lists of observations as well as theoretically ambitious treatises. ${ }^{61}$ It is also important, however, to listen to Hell's laments concerning the impact of the Society's suppression, which were quite frequent. In one of these, he wrote in 1790:

As a result of this dissolution of the Society of Jesus, I was utterly deprived of all those assistants and adjuncts, paid by the Society of Jesus, who used to aid me in my astronomical duties and activities. Thus, by my own efforts solely and uniquely I must both do the calculations for the annual Ephemerides astronomicae and preside over their publication, as well as take care of the planning, conducting, and continuation of astronomical observations, and even take care of my scientific correspondence with astronomers all over Europe (in addition to Beijing in China); and whatever other astronomical tasks that called for my attention, must be done without any assistants or adjuncts, solely and uniquely by myself.

Unlikely Settings," in O'Malley et al., Jesuits, 2:772-83. But even for those who stayed in Central and Western Europe, the survival of the Society in the East was of symbolic importance: devout ex-Jesuits—-Hell among them—-looked to Prussia and especially Russia for comfort.

59 Besides Haberzettl, Stellung der Exjesuiten, see Trampus, I gesuiti e l'Illuminismo; Müller, "Der Jesuitenorden und die Aufklärung"; and Ritchie Robertson, "Curiosity in the Austrian Enlightenment," Oxford German Studies 38 (2009): 129-42.

6o See, e.g., Bernoulli, Nouvelles littéraires 1 (1776): 9-10.

61 There were some difficulties, though, with the production. In the mid-1770s, a conflict of interest seemed to arise between Hell and the publisher, on which see the discussion of Hell's scientific academy plans below. A decade later, Hell complained about the "chaos" arising in the printing house from the frequent changes of the workers, and the extra burden resulting from his own agreement to publish the Ephemerides not one but two years in advance of the given year. Hell to Kästner in Göttingen, March 6, 1786 (NSUBG; see Hungarian translation in Csaba, Hell Miksa írásaiból, 58 ). 
In this time of hardship, I was left only with two choices: either to bid farewell to my chair as imperial and royal astronomer, if I wished to finish my vast, three-volume work Expeditio litteraria as promised, or to suppress this work, if I decided to continue in my chair as an astronomer, a chair in which I, for as long as the Society of Jesus existed, was helped by assistants in my work. ${ }^{62}$

In other words, while the routine activities of the observatory-those prescribed to Hell in the instructions of 1755 - were indeed unaffected, the logistics had to be revised. What emerges from these lines is that, before 1773, the imperial and royal astronomer was able to delegate such basic tasks to personnel put at his disposal not by the maintainer (the state), but via the established practices of apprenticeship in the Society of Jesus, so that he could dedicate a good part of his own time and energies to other scientific projects. Hell also seems to have staked the execution of his ambitious plan of publishing a comprehensive, multi-volume account of the Arctic expedition on the continuation of such arrangements, and he blamed the failure of completing the magnum opus on the frustration of these expectations by the suppression of his order, as a result of which he was forced to deal with much of the daily chore himself.

To be sure, this was still far better than the fate of the Jesuit Observatory of Vienna, just two-hundred meters away, which was closed shortly after the suppression of the Society. The director Liesganig was appointed professor at the former Jesuit college of Lviv in Galicia, which had come under Austrian rule in the aftermath of the first partition of Poland in $1772 .{ }^{63}$ As mentioned above, from his base in Lviv Liesganig conducted extensive surveys of the new Habsburg province of Galicia and served as the director of an observatory that had been founded by the Jesuits around $1771 .^{64}$ As Liesganig passed away in

62 Maximilian Hell, "Observationes astronomicae latitudinum, \& longitudinum locorum borealium Daniae, Sueciae, Norwegiae, \& Finnmarchiae Lapponicae per iter arcticum annis 1768, 1769, \& 1770 factae," Ephemerides 1791 (1790), 301-2.

63 The Jesuit college of Lviv was founded in 1661 and received papal approbation as a university as late as 1759 , a status it lost in 1773 . For the next decade, it was known as the Theresianum, or academy for noblemen, until Joseph II renewed its university status in 1784 .

64 In some of the literature, this observatory is missing entirely, cf. Derek Howse, "The Greenwich List of Observatories: A World List of Astronomical Observatories, Instruments, and Clocks, 1670-1850," Journal for the History of Astronomy 17, no. 4 (1986). Elsewhere, it is conjectured that it was founded by Liesganig, who came to Galicia in 1774, cf. Udías, Searching the Heavens, 31. However, an engraving of "the observatory of the Jesuit college, 1771" is included in Brosche, Der Astronom der Herzogin, 25. Von Zach, in an article in his Monatliche Correspondenz 4 (November 1801): 547-57, here 550, claims that a Jesuit 
1799, he left a large collection of manuscripts from his surveys in Galicia. However, just as earlier, he did not submit any observations from Lviv to the Ephemerides astronomicae edited by Hell and then von Triesnecker. Back in Vienna, the Jesuit observatory seems not to have been manned at all after Liesganig's departure for Lviv in 1774. In a much later letter to Weiss, Hell explains that "I have managed to save the observatory of the Viennese academic collegium, which surely, in case I had been absent from Vienna at that time, would have been removed and demolished, because the architect had misunderstood the words of the emperor." ${ }^{65}$ The Jesuit observatory is described as still in existence in Pilgram's work on meteorology published in 1788. Exactly when it was demolished is not known. ${ }^{66}$ As to Hell's action to preserve it, this may be interpreted as a sign of his hopes that the Society of Jesus would one day be restored and activities resumed at the former observatories. ${ }^{67}$

Before the suppression, the Society of Jesus had been in a position to construct observatories and equip them with instruments and personnel by its own means. Although the growth around 1750 was followed by a period of standstill, it remains a fact that between 1745 and 1756 the number of Jesuit observatories grew from one (Vienna) to three (Graz and Trnava added). In the course of the 1750s, the Benedictines constructed their sole observatory in Kremsmünster, led by Fixlmillner, and the state funded the Imperial and Royal Observatory in Vienna, headed by the Jesuit Hell. No major expansions appear to have taken place during the 1760 s. Just on the threshold of the calamity of 1773, however, the Jesuits found that the time was ripe for new establishments.

observatory existed in Lviv "since long before the Austrian occupation of Galicia and Lodomeria in the year 1772." As proof, von Zach points to the observation of a solar eclipse made by Hell's former student Lysogorski in 1764. It was this same Lysogorski that had left Vienna for Lviv in 1761, allegedly equipped with a decent set of instruments, but he seems never to have fulfilled Hell's high hopes as stated in his 1761 Venus transit report (cf. above, Chapter 3). Thus, according to the authors of the article "First Astronomical Observatory in Lviv" (S. Apunevych et al., in Kinematics and Physics of Celestial Bodies 27, no. 5 [2011]: 265-72), Lysogorski's observations were made from the mansion of Archbishop Sierakowski, whereas the date of foundation of the Jesuit observatory was as late as May 15, 1771, without Lysogorski playing a part. Instead, a certain Ludwik Hoszowski (1732-after 1773) served as professor of mathematics at the Jesuit college in Lviv from 1769 to 1773 according to Fischer, "Die Jesuiten-Mathematiker des Nordostdeutschen Kulturgebietes," 139-47. During 1771-73, Hoszowski was also entered in the Jesuit catalogs as professor of astronomy and prefect of the "mathematical museum" in Lviv. After the suppression of the Society of Jesus, Hoszowski left for an ecclesiastical post in Przemysl and seems never to have become part of the team around Liesganig.

65 Hell to Weiss, dated Vienna, November 12, 1783 (Vargha priv.).

66 Steinmayr, "Geschichte der Universitätssternwarte," 178.

67 Cf. Hell's letter to Bernoulli in Berlin, dated Vienna, February 15, 1777 (U Bв). 
Enlightened interest in astronomy certainly peaked around the transit of Venus in 1769, and when Hell returned as an explorer of worldwide reputation in the following year, the conditions for a revitalization of institutional astronomy were probably as good as they could ever become.

The failure to finalize the construction of an observatory even by this time at the Jesuit college of Cluj, where Hell had been appointed to oversee it in the 1750s, has already been mentioned. That of Buda, the old capital of the Kingdom of Hungary, is a similar story. A Jesuit convent was established there almost immediately after the liberation of the town from the Ottomans in 1686, and a college was in full operation by 1701. The first professor of mathematics was appointed there in 1744, and soon after Hell and Sajnovics returned from their expedition, the post was given to Sajnovics. At the same time, plans were being laid to make the former assistant of both Hell (Vienna, Vardø) and Weiss (Trnava) the director of a new Jesuit observatory in conjunction with the Buda college. ${ }^{68}$ With scarcely concealed pride, Sajnovics exclaimed: "I am destined to become a professor in Buda, where I am supposed to lay the foundations for practical astronomy. In this way, I hope to become the royal astronomer of Hungary, which is the most illustrious title I can ever imagine." ${ }^{69}$ In the abovementioned letter to Bernoulli, Hell explains that as the suppression of the Society arrived in 1773, everything was ready, the funds had been secured, and Sajnovics appointed for the job of supervising the construction. ${ }^{70}$ Evidently, the suppression of the Society of Jesus brought these plans to a halt.

At the dawn of the 1770s, the Jesuits did not limit themselves to their plans for expansion in Cluj and Buda, but also promoted developments outside their own ranks. While the Benedictines founded and maintained a high-standard observatory in Kremsmünster, the historiography on the order's role in the history of Central European astronomy is meager. It is clear, though, that the pressure of the anti-monastic sentiment gaining currency in the period had consequences in this regard, too. An attempt was made in the late 1760 os and early 1770 s to establish an observatory at the splendid Benedictine monastery of Melk, ${ }^{71}$ whose abbot tried to set in place various innovations in order to give

68 In a letter to Weiss, dated Vienna, May 24, 1771, Hell wrote (Vargha priv.; also found in Pinzger, Hell Miksa, 2:106): "I have not yet been able to discuss the Buda observatory with the honorable pater provincialis [i.e., the head of the Austrian Society of Jesus]. I would really hope that astronomy may be cultivated in the very same place that I, as a teacher of mathematics so long ago, had planned to become my workplace."

69 Sajnovics to János Nagy, dated Trnava, May 12, 1771, facsimile in Kisbán, Sajnovics, 40-41.

70 Hell to Bernoulli in Berlin, dated Vienna, February 15, 1777 (Ч в B).

71 Gottfried Glaßner and Christina Preiner, "[...] Physica autem sine omni experimento sicca sit et sterilis': Warum im Jahr 1771 trotz guter Argumente der Plan, in Melk eine 
his institution a more "modern" profile. One of the plans he nurtured was remaking the monastery's powder tower into an astronomical observatory. The abbot was encouraged in this project by, among others, the Jesuit astronomers Paolo Frisi (1728-84) from Milan and Liesganig from Vienna, who both paid visits to Melk in order to offer support and advice. In the end, however, this project was also dropped because of internal strife within the monastery.

Somewhat later, a modest Benedictine observatory was in fact founded at the monastery in Lambach. In a letter to Bernoulli in Berlin from the summer of 1777 , Fixlmillner explained that an observatory was being established at this place, and that a monk by the name of Julian Ricci $\left(1745^{-1812}\right)$ had been sent from the abbey to Vienna to receive instructions. ${ }^{72}$ Ricci stayed at Hell's place in Vienna for several months, until he traveled back to Lambach in the autumn of 1777 along with the imperial astronomer, who was to assist in the practical arrangements for this observatory. ${ }^{73}$ Whatever its position internally in the Benedictine system, the observatory in Lambach never gained anything near the prominence of its Kremsmünster counterpart. In the latter place, Fixlmillner continued his observations as before, unaffected by the Theresan and Josephian monastic reforms. His observatory became a "node" of European astronomy in its own right, but Fixlmillner seems not to have promoted his colleague in Lambach or his observations to any significant extent.

No further attempts to establish astronomical observatories either by religious orders or private individuals seem to have been made in the geographical area of the former Austrian province of the Society of Jesus during, or in the aftermath, of the suppression. The plight of the Jesuit observatories that were in operation as the suppression arrived remains to be described. The Jesuit observatory of Vienna has already been mentioned, and the less-than-glorious early history of its younger sister observatory in Graz has also been summarized

Sternwarte zu errichten, nicht zur Ausführung kam," in "[...] und das Firmament kündet vom Werk Seiner Hände" (Ps. 19:2): Faszination Astronomie; Eine Spurensuche in der Melker Stiftsbibliothek, ed. Gottfried Glaßner, Thesaurus Mellicensis 1 (Melk: Stift Melk, 2009), 123-31.

72 Fixmillner to Bernoulli in Berlin, dated Kremsmünster, June 23, 1777 (printed in Bode's Astronomisches Jahrbuch and quoted in the JS [December 1778]: 801-15, here 814). "Il dit, à la fin de sa Lettre, qu'on va établir à l'Abbaye de Lambach, près de Cremsmunster, un Observatoire; \& qu'un Religieux de cette Abbaye est à Vienne pour prendre les instructions nécessaires." For Ricci, see Rabenalt, “Astronomische Forschung," $129 n 2$.

73 In a letter to Bishop Eszterházy in Eger, dated Vienna, September 8, 1777 (FLE AV 2629), Hell wrote: "Tomorrow, that is, the 9th of September, I will go to Upper Austria along with another astronomer of the Benedictine Monastery of Lambach. I have trained him in astronomy for four months, and upon invitation from the Most Honourable Abbot I will go there to arrange a new observatory that has been constructed at that place." 
in Chapter 2. The latter was also closed not long after the suppression of the Society in 1773. Its last director was almost certainly Anton Mayr (or Mayer $[1738-?]){ }^{74}$ Born in Vienna, Mayr entered the Society of Jesus around 1756, held a chair as "professor of higher mathematics" (prof[essor] math[eseos] repet[itae]) in Graz in $1765^{-72}$, before being appointed director of the astronomical observatory there for the university year $177^{2-73 .}{ }^{75}$ At the latest by 1776, however, Mayr's days in Graz were over. His chair was judged to be redundant and became abandoned, and the observatory itself was at first closed, and then finally demolished in $1787 .{ }^{76}$ Mayr returned to Vienna, where he had a short career at the side of Hell: on the title pages of the Ephemerides astronomicae for the years 1777 and 1778 , he is presented as a calculator of the almanac as well as Hell's adjunctus. In November 1776, Hell explained to Bernoulli that to replace his two former assistants "I have received only one, the adjunct Anton Mayr. He is an ex-Jesuit, but will need to be instructed in astronomical calculations first" (a rather peculiar comment on an individual who had already served a period as the director of an observatory). ${ }^{77}$ It appears that these instructions were no success, for after 1777 Mayr is no longer mentioned as Hell's assistant in the Ephemerides. ${ }^{78}$ His subsequent whereabouts are uncertain, except that he published a book on poisonous frogs in Vienna in 1783 . He is said to have died there, but not even the year of death is known. ${ }^{79}$

The career of another representative of the Graz university, Triesnecker is far better known. Born in Mallon close to Kirchberg am Wagram in Lower Austria, he entered the Society of Jesus in 1761 and studied philosophy in Vienna and mathematics and languages in Trnava. In 1770-71, he taught humanities in Linz before enrolling as a student of theology in Graz. Despite the suppression of the order, von Triesnecker continued his studies to become a doctor of philosophy in Graz in 1775. Von Triesnecker's biographer has not been able to

74 According to Michaela Scheibl at the Universitätsbibliothek Graz, his real name was not Anton, but "Alois Mayr." Under this name, on April 9, 1774, the ex-Jesuit Mayr was granted a salary of five hundred gulden to serve as professor of astronomy in Graz. Communication by e-mail from Michaela Scheibl to Per Pippin Aspaas, January 17, 2011.

75 Fischer, "Jesuiten-Mathematiker in der Deutschen Assistenz."

76 Schreiber, "Jesuit Astronomy (Part I)," 16.

77 Hell to Bernoulli in Berlin, dated November 30, 1776 (Uвв).

78 It may be this adjunct Father Hell refers to in a letter to Wargentin in Stockholm, dated Vienna, July 29, 1778 ( $\mathrm{CVH}$ ): "Lacking assistance from my adjunct, who is constantly ill, I have not had the time needed to write scientific works."

79 Information on Anton Mayr, unless otherwise stated, has been found in Cornelia Maria Schörg, "Die Präsenz der Wiener Universitätssternwarte," 100; Fischer, "Jesuiten-Mathematiker in der Deutschen Assistenz" (Schörg has not used Fischer); Wurzbach, Biographisches Lexikon (1868), 18:82-83. 
establish his whereabouts in the interval from 1775 to 1780 , in which year (or early in the next one at the latest) he emerged as the adjunct of Hell in Vienna. Von Triesnecker was to stay in this role throughout the 1780 s and early $1790 \mathrm{os}$. After Hell's death in 1792, he inherited the position of imperial astronomer, and kept it until his own passing in 1817. As an editor of the Ephemerides and its appendices, von Triesnecker loyally followed the principles that had been laid out by his predecessor until the series eventually had to be discontinued in 1806 as a result of financial problems caused by the Napoleonic Wars. ${ }^{80}$ Unlike Mayr, von Triesnecker appears to have been a success as an adjunct. Exactly who taught him astronomy is not known, but it is tempting to conjecture that he learned the rudiments of astronomy in Graz before he was called to Vienna at the age of thirty-five. Like Liesganig, von Triesnecker was to become an active surveyor in the service of the state: in the 1790s and 1800s, he took part in field works in both Galicia and Lower Austria. ${ }^{81}$

In the Kingdom of Hungary, developments for former Jesuits were slightly more auspicious than in Austria. ${ }^{82}$ The leading astronomer on Hungarian soil, Franz Weiss, remained the director of the university observatory in Trnava until 1777, when it was decided that the university itself was to be moved to Buda. A new observatory was then constructed at the new Royal Palace in Buda, with the imperial astronomer taking part in the construction process by personally traveling to Buda and providing advice in the spring of $1777 .{ }^{83}$ By 1779 , construction works were finished. Observations began in 1780 , with Weiss the undisputed director. Sajnovics was to remain in the background, and although he did publish a textbook of astronomy in $1778,{ }^{84}$ he never received a chair as a professor of astronomy, far less the title "royal astronomer," which he had dreamed of a few years earlier. Whether Sajnovics formally took over as director

8o On von Triesnecker's career, see Wurzbach, Biographisches Lexikon (1883) 47:197-99; Schörg, "Die Präsenz der Wiener Universitätssternwarte," 83-86; Nora Pärr, "Wiener Astronomen: Ihre Tätigkeit an Privatobservatorien und Universitätssternwarten," Diplomarbeit (Vienna: Geisteswissenschaftliche Fakultät der Universität Wien, 2001), 41-43; Kastner-Masilko, Triesnecker, passim. Kastner-Masilko's biography should, however, be used with caution, see Per Pippin Aspaas's review in Beiträge zur Astronomiegeschichte, ed. Wolfgang R. Dick and Jürgen Hamel, 9, Acta historica astronomiae 36 (2008): 269-73.

81 Kastner-Masilko, Triesnecker, 116-23.

82 For an overview, see Paul Shore, "Enduring the Deluge: Hungarian Jesuit Astronomers from Suppression to Restoration," in Jesuit Survival and Restoration: A Global History 1773190o, ed. Robert A. Maryks and Jonathan Wright (Leiden: Brill, 2015), 148-61.

83 Hell to Bernoulli in Berlin, dated Vienna, June 20, 1777 (UBB).

84 János Sajnovics, Idea astronomiae (Buda: Landerer, 1778); reprint with a Hungarian translation, ed. Rezső Nagy (Székesfehérvár: n.p., 1993). 
in the interval between Weiss's passing in January 1785 and his own death in May of the same year is unclear.

After Weiss's departure for Buda in 1777, a former assistant of his and another ex-Jesuit, Franz Taucher (1738-1820), took over as director at the observatory in Trnava. Originally from Cluj, Taucher was educated in Trnava during the flourishing period of the Austrian province. When Sajnovics left for Vardø in 1768-69, Taucher rose to the rank of adjunct and finally director. After Weiss and the rest of the university staff and students had left, Taucher carried on a dreary existence at the former university compounds until the year 1785 , when Weiss passed away. ${ }^{85} \mathrm{He}$ then brought with him the remaining instruments from the Trnava observatory to Buda, where he once again followed in the footsteps of Weiss as director of the university observatory, a position he retained until his retirement in $1806 .{ }^{86}$ After 1785 , the observatory of Trnava was neither equipped nor manned. The team in Buda included an assistant - first to Weiss and then to Taucher-a Hungarian-Croat ex-Jesuit born in Zagreb, Ferenc Xavér Bruna (1745-1817), appointed as professor of mathematics in 1798 and even emerging to the rector's seat in 1811 .

The downfall of the Jesuit order thus prevented what might have become a "second wave" of observatory establishments in Habsburg-ruled lands after the "first wave" in the period from the mid-1730s to the mid-1750s. Without the resources of the Society of Jesus, it was up to the state or the still surviving orders to fund new institutions. The claim that the status of the ex-Jesuits in astronomy remained unchallenged is true in the sense that there were no obvious inheritors or competitors. It is, however, correct only from a strictly internalscientific point of view. Seen from another angle, the Jesuits had now lost their ability to decide for themselves, since all former colleges, including their observatories, had been taken over by the state. The imperial astronomer himself was never removed, but other Jesuit astronomers became more vulnerable, which may be illustrated with a few further examples.

The title page of the Anni 1776 volume (published 1775) of the Ephemerides astronomicae states that this particular issue had been "determined through calculations made under the direction of Maximilian Hell, by the Honorable Freiherr Ignaz Baron von Rain (1737-after 1776) and Franz Güsman (1741-1806),

85 Taucher's letters to Weiss in Buda from this period (e.g., those dated Trnava, August 29, 1776, May 5, and December 4, 1784) offer dark reading. Witness, for example, his constant fear of a decree ordering the closing down of his observatory; his sentimental account of the celebrations of Saint Loyola, patron saint of the Jesuit order; or his stubborn refusal to give Emperor Joseph II, sworn enemy of the Jesuits, access to the observatory during his visit to Trnava in 1784. Vargha, Correspondence de Weiss, 1:127-28, 2:210-13.

Vargha, Correspondence de Weiss, 2:226-27. 
astronomers of the university." The former, born in Rijeka (Flumen, Fiume, Vitopolis, Szentvit, Sankt Veit am Pfaum) in present-day Croatia, entered the Society of Jesus in $1753 .{ }^{87}$ Of noble birth, he was educated at the Theresianum in Vienna, presumably with Scherffer as his foremost teacher in astronomical subjects. He is probably identical with a certain M. Rain S.J. repetens matheseos (M[agister?] Rain of the Society of Jesus, teacher of mathematics) that observed the Venus transit from the Imperial Observatory in $1761 .{ }^{88}$ The same Rain is also said to have served, this time as "second assistant," at Hell's observatory in the year 1770, during Hell's absence in Denmark-Norway. ${ }^{89}$ In the university years $1771^{-73}$, however, Rain held the chair as professor of mathematics at the college in Linz, while a letter from Hell to Bernoulli reveals that by 1776 Rain had already departed for a post as a professor of mathematics in Lviv. ${ }^{90}$ Rain here served as an assistant of Liesganig in his survey of Galicia, where he may also have ended his days. ${ }^{91}$ In any case, his post-suppression collaboration with Hell and the Ephemerides was limited to the Anni 1776 volume. The other character mentioned in the same quality in the same volume, Franz Güsman (or Güssmann, Gueßmann, Guessmann) was born in Wolkersdorf (just north of Vienna), and entered the Society of Jesus in 1757 . He was preparing for departure for the Jesuit missions in China just as the suppression arrived in $1773 .{ }^{92}$ His participation in the calculations of the Ephemerides appears to have been limited to the year in question. By November 1776, Güsman had left Vienna and arrived — along with Rain—in Lviv to take up a chair in physics. ${ }^{93}$ Also like Rain, he took part in Liesganig's survey of Galicia from the late 1770 s onward. In 1787, he returned to Vienna, allegedly because of health problems, and was appointed professor of experimental physics at the Theresianum. ${ }^{94}$

87 Dates according to Steinmayr, "Geschichte der Universitätssternwarte," 199-200. The year of 1757 as Rain's year of birth as given in Fischer, "Jesuiten-Mathematiker in der Deutschen Assistenz" must be a misprint, for he is also said there to have entered the Society in 1753 . Hell, "Observatio transitus Veneris [...] 1761," 17. In a letter to Taufferer in Ljubljana, dated Vienna, April 6, 1761, Hell speaks of a bidellus (assistant, servant) by the name of Rain. One of Hell's biographers also states (sadly, without source reference) that Hell received assistance from "Ignác Rain” in 1760-61. Ferencová, Maximilán Hell, 29.

89 Steinmayr, "Geschichte der Universitätssternwarte," 200, likewise without source citation.

9o Hell to Bernoulli in Berlin, dated Vienna, November 30, 1776 (Ч вв).

91 Information on Rain, unless otherwise noted, has been culled from Fischer, "JesuitenMathematiker in der Deutschen Assistenz."

92 Steinmayr, "Geschichte der Universitätssternwarte," 181.

93 Hell to Bernoulli, dated November 30, 1776 (Чвв). The content of this letter is reiterated (in French) in the second cahier of Bernoulli's Nouvelles littéraires (1777): 8-9.

94 Haberzettl, Stellung der Exjesuiten, 168. See also Brosche, Der Astronom der Herzogin, 22-23. 
He taught partly there and partly at the Wiener Technische Hochschule, until he retired and eventually died in Seitenstetten. ${ }^{95}$

However limited the evidence we have on some of these figures, it is striking to see both that Hell still had some means left to recruit his collaborators from former Jesuit circles, and the limits of those means. As an ex-Jesuit, he was at least not entirely isolated from his former Jesuit network. But he had difficulties retaining these assistants: when the state called them to imperial purposes outside Hell's sphere of influence, they disappeared from sight. The infrastructure for practical astronomy was still in place, and the very continuation of the Ephemerides is strong testimony that theoretical work was being done at Hell's observatory in Vienna. But Hell's work pace was definitely affected negatively, and —above all—as a "nodal astronomer" he had lost much of his momentum and impact. The fate of observatories across the Habsburg lands depended on the preferences of other decision-makers. The Jesuit observatory of Graz was quickly closed, and those of Trnava and Vienna followed in its wake. Instead of growth in the number of observatories, there came a period of decline. The Benedictine order made no considerable expansion in astronomy, either: only a minor "satellite" was added to its prestigious observatory of Kremsmünster in nearby Lambach. New university observatories in Buda and Lviv, both run by ex-Jesuit staff, were neither sufficient to foster a new generation of astronomers, nor provide career opportunities to those trained elsewhere.

Secular talent thus also hardly found more opportunities in the Viennaruled territories after 1773 than earlier. An example is the highly gifted Franz Xaver von Zach, whom we have already met briefly in conjunction with the posterior defamation of Hell's Venus observation results. Between his fallout with Liesganig in Galicia and his European journey, which eventually managed to secure him sufficient patronage to embark on a career in Germany, von Zach traveled to Vienna in 1781-82 in search of a position, and appears to have visited Hell, to no success. ${ }^{96}$ Having finally established himself in Gotha and become one of Europe's leading astronomers by the turn of the century, von Zach's bitterness toward the Jesuits never waned, and in his publications he continuously accused them of devious scholarly practices as well as nepotism designed to keep outsiders out of science. ${ }^{97}$

95 Information on Güsmann, unless otherwise noted, has been taken from Wurzbach, Biographisches Lexikon (1860) 6:21-22; cf. Schörg, "Die Präsenz der Wiener Universitätssternwarte," 99.

96 Brosche, Der Astronom der Herzogin, 31.

97 See Brosche, Der Astronom der Herzogin (with ample references). 
Some of von Zach's accusations toward Liesganig and Hell sound, as we shall see, like resonances of the contemporary anti-Jesuit propaganda pursued by freemasons (von Zach was, by the way, a freemason himself). However, it should be stressed that it was not only the ex-Jesuits who made things difficult for aspiring astronomers in Central Europe in the final quarter of the eighteenth century but factors that also affected former Jesuits themselves. The utilitarian approach promoted by Joseph II implied some reluctance to direct resources toward sciences that were not "useful" - if one is to believe Hell, who complained about this situation in a letter to Bernoulli in 1777 :

The above-mentioned damages that have been inflicted upon Austrian astronomy by the destruction of my order are, however, less grave than the fate that would have befallen the observatories that once upon a time were erected by the Society, namely the ones in Bohemian Prague, in Styrian Graz, and at the academic collegium in Vienna, in case I had not-encouraged by a hope that our Society will one day be brought back to life - resisted it with all my might. For you see, there are enemies of the Society and of the hard sciences who have persuaded Her Highness the Empress that these three observatories, which our Society once erected and equipped, were worthy of being destroyed and demolished because they allegedly were superfluous and thus extracting worthless funds for their conservation. Enough worthless funds, they said, were already being spent on the Imperial Observatory of Vienna and on the observatory in Trnava, for "the sole purpose of retaining reputation abroad." And in order to eliminate astronomy along with the Jesuits, they claimed that astronomical observatories were useless to rulers except for those who have a fleet at sea or are engaged in maritime trade; accordingly, since the lands subjected to Austria lack these properties, the observatories were of no use, the astronomers were of no use, and all funds were unworthy of being wasted on astronomy: as if astronomy had no use except for navigation!98

In Hell's rendering, the dominant ideology under Joseph II had little respect for the heritage of Jesuit science not merely because it was Jesuit but because

98 Hell to Bernoulli in Berlin, dated Vienna, February 15, 1777 (UBB). Transcriptions in Aspaas, "Maximilianus Hell," 176, and Aspaas, Posch, and Müller, "Astronomische Observatorien der Jesuiten in der 'Provincia Austriae,"” 108, which were based on scannings from the University Library of Basel, contain conjectures that have been verified during a recent inspection of the original manuscripts. 
of its allegedly non-utilitarian character. We have seen that although Hell lingered in Vienna, Liesganig and Weiss were moved to Lviv and Buda, respectively, upon orders from the state, and at least in the case of the former involved in a project immediately serving practical purposes of the state. None of these three places are indeed likely to have been particularly welcoming to "new men" in astronomy; there were enough former Jesuits around to recruit for the few vacancies that existed. Altogether, it would be harsh to subscribe to von Zach's verdict that the nepotism of ex-Jesuits was the main problem. If the observatory of Buda is discounted as a replacement for that of Trnava, we find that the only new facility for institutional astronomy created in the former Austrian province of the Society of Jesus in the fifteen years following the year 1773 was founded and funded not by the modernizing state, but by Eszterházy, the conservative bishop of Eger in eastern Hungary. In the last chapter, we shall examine the development of Hell's relationship with this new hero of his, besides pursuing the imperial astronomer in the labyrinths of metropolitan and provincial politics and controversies during the final period of his career. 